\title{
Research on the "three win" Mode of "school enterprise combination" Innovation and Entrepreneurship Education in Business Administration Major
}

\author{
Xinjun Wang \\ Business School, Shandong University of Technology \\ Zibo, China \\ Email: lhk8068 [AT] 163.com
}

\begin{abstract}
Under the national strategic background of "mass entrepreneurship and innovation", the integrated resources of "school enterprise combination" and integrated resources are working together to help the innovation and Entrepreneurship of college students, and the gradual formation and improvement of the training mode of innovative and entrepreneurial talents in Colleges and universities are becoming more and more important. The "three win" model of entrepreneurship education has become an important goal of business management education. School enterprise cooperation is an important direction of college education reform, and also an important direction for the reform of business administration.
\end{abstract}

Keywords--- school enterprise combination, Business Administration Major, innovation

\section{INTRODUCTION}

Since 1987, our university has set up the major of industrial management engineering. In 2002, it was upgraded to a major of business management. Since the professional setting up, the Department of business and Commerce has carried out continuous exploration and summary on the curriculum, teaching mode and curriculum system. It has been graduated from undergraduate students for more than 1500 students, and has obtained a high satisfaction rate of social employment, We have set up second major and minor major, and got master's point of enterprise management (2006) and master's degree of master of business management (2010), which created a good atmosphere for study.

\section{WORK BASE}

1. Professional personnel training specifications

In the field of professional talents training, business administration major should adhere to the following guidance: to serve the guidance of the development of students, to meet the rapid development of the economy and to meet the needs of the society, and to be in line with the training and positioning of the applied talents. In 2016, it set up a two degree course in entrepreneurial management. In 2015, the business management specialty ranked third in Shandong Province, encouraging teachers to integrate the latest frontier knowledge of the subject, the latest technology of the industry, the personal scientific research results and practical experience of teachers into the classroom teaching, and encourage teachers to strengthen innovation and entrepreneurship education in the course of teaching professional knowledge and promote innovative and entrepreneurial education and professional education. To integrate and guide students to form the idea of innovation and entrepreneurship. Up to now, business administration major has formed a curriculum system and teaching system based on knowledge, ability and quality.

2. Curriculum construction

According to the goal of innovation and entrepreneurship education, innovation spirit, entrepreneurial consciousness and innovation and entrepreneurship are the important indicators of talent training. In 2016, the business administration major revised the undergraduate program in an all-round way and perfected the top talent, outstanding talent, innovative entrepreneur training program and teaching program. To promote the integration of professional education and innovation and entrepreneurship education, business management majors have set up compulsory courses such as "entrepreneurship management" and "entrepreneurial opportunity identification" for all professional direction students, and set up an elective course group of entrepreneurial management on the basis of the direction of entrepreneurship management. It has basically formed a creative and entrepreneurial curriculum system composed of innovative and entrepreneurial curriculum group, special curriculum group, "professional + innovation and entrepreneurship" integrated curriculum group and practical course group.

3. Reform of Teaching Methods

The specialty of business administration is actively carrying out the reform of teaching methods. At present, all the courses have adopted three courses to obtain the comprehensive reform project of the school curriculum. In 
this way, it is a turning point to guide the business management teachers to improve the teaching model, strengthen the teaching design, and use case discussion in the course of teaching. The method has realized heuristic and inquiry teaching. At the same time, improve the assessment methods and content, ten courses have been relying on the school network teaching platform to achieve a mixed teaching. Teachers should be encouraged to integrate the latest frontier knowledge of the subject, the latest technology of the industry, the personal scientific research results and practical experience of teachers into the classroom teaching, and encourage the teachers to strengthen the innovation and entrepreneurship education in the course of teaching professional knowledge, promote the integration of innovative entrepreneurship education and professional education, and guide the students to form the concept of innovation and entrepreneurship. At present, a better teaching management supervision and evaluation system has been set up, and a series of teaching management systems, including new teachers' trial, new course trial, teachers' listening to each other, and teaching observation and so on are set up.

4. Fulfillment training

Through the establishment of the relationship between the teaching system and the practice system, at present, all the courses will combine the three schools, students and enterprises organically, and build a cooperative platform among the three, and initially realize the open cooperative teaching system for the school, the students and the enterprises, including: to carry out the career navigation activities and to the students. Planning for the future; using innovative teaching methods, combined with simulation experiment teaching, providing students with a good environment for theoretical learning and skill training; carrying out a series of innovative exhibition activities to build a practical training platform for students to improve their awareness of innovation during the school period. At the same time, with the establishment of a long-term practice base with the enterprise, the teachers organize the students to enter the enterprise practice and other cooperation channels, the experienced teachers organize the students to enter the enterprise to participate in the practice, and provide more services to the enterprises on the basis of guiding the students. Through the research results for the service of the enterprise, it can not only help the enterprise to obtain more benefit return, but also make the students get the practice ability and the innovation ability. Relying on the simulation practice of enterprise management, the school takes the practice base as the focus and both inside and outside, and strengthens the combination of case teaching, practice teaching and simulation teaching inside and outside the class, fully exerts the role of professional practice base and outstanding entrepreneurs, and strengthens and promotes the students' ability to apply professional knowledge. The laboratory for business administration specialties is 100 square meters. It mainly takes on the teaching of practice courses such as "simulation practice of enterprise management" and "simulated practice of sand table".

\section{CONSTRUCTION OBJECT}

In order to train the training goal of "Five" talents, we should guide college students to change employment concept to meet the needs of market economy, cultivate students' self-reliance spirit, strengthen their entrepreneurial ability, alleviate social employment pressure, cultivate college students' innovative spirit, improve employment and entrepreneurial ability, and realize "students, schools and enterprises" together. As a guiding principle, we should comprehensively deepen the reform of innovation and entrepreneurship education in business administration. By 2020, we should form an innovative and entrepreneurial education system and system environment that adapt to the requirements of innovation driven development, integrate classroom teaching, independent study and practice training, form an advanced scientific training model for talents, and build a "three win" model of "school enterprise combination" of College Students' innovation and entrepreneurship education.

\section{REFERENCES}

[1] Li Z. Research on the Cultivation Mode of Innovative and Entrepreneurial Talents in Business Administration Key Major Groups[J]. Science Education Article Collects, 2014.

[2] Jing-Bin Y U. Research on the Combination of Innovation and Entrepreneurship Education with Ideological and Political Education in Higher Vocational Colleges[J]. Journal of Heilongjiang College of Education, 2018.

[3] Jin Y. Innovation and Entrepreneurship Education Reform of Business Administration Major: A Chinese Case Study[J]. 2016, 5(2):27.

[4] Liu Y, Wang D Z, Zhao H M. Research on Talent Training Mode of Business Administration Professionals based on Innovation and Entrepreneurship Education[J]. Pioneering with Science \& Technology Monthly, 2017.

[5] Li C. Research on Innovation and Entrepreneurship Education under the Mode of School Enterprise Cooperation[J]. Education Teaching Forum, 2017. 